Article

\title{
Enablers and Constraints of Female Entrepreneurship in Khyber Pukhtunkhawa, Pakistan: Institutional and Feminist Perspectives
}

\author{
Mohammad Sohail Yunis ${ }^{1}{ }^{\mathbb{D}}$, Hina Hashim ${ }^{2, *}$ and Alistair R. Anderson ${ }^{3}$ \\ 1 Institute of Management Sciences (IMSciences), 1-A, E-5, Phase VII, Hayatabad 25000, Pakistan; \\ sohail.younis@imsciences.edu.pk \\ 2 Swedish University of Agricultural Sciences, Institutionen for ekonomi, Box 7013, 75005 Uppsala, Sweden \\ 3 Lancaster University Management School, Bailrigg, Lancaster LA1 4YX, UK; a.anderson@lancaster.ac.uk \\ * Correspondence: hina.hashim@slu.se; Tel.: +46-73-5948-534
}

Received: 1 October 2018; Accepted: 28 November 2018; Published: 21 December 2018

\begin{abstract}
Entrepreneurship is often considered a male-gendered concept, and carries masculine connotations. However, the importance of women entrepreneurs and their contribution to the economy has recently been realized. Nonetheless, there is limited research about female entrepreneurship and social entrepreneurship in the developing countries context. This paper challenges the implicit masculinism of the traditional entrepreneurship research, and aims to explore the enablers and constraints of female social entrepreneurship within the context of a developing country. Our theoretical focus is based on institutional and feminist perspectives, thus developing logic through reconciling predictions from these two competing theories. This integration contributes by offering novel insights about social entrepreneurship. Utilising an interpretive qualitative research approach, data from in-depth interviews with ten female social entrepreneurs of KP, Pakistan were analyzed using thematic analysis. Empirically, we identify and discuss a number of interesting and explanatory themes affecting female entrepreneurship such as "women empowerment, patriarchal culture, role of culture and societal norms, religious extremism and terrorism, forced entrepreneurs, change creators, unique institutional constraints, institutional corruption and security issues". The findings highlight female entrepreneurs' struggle for sustainability, and explain how this occurs. The paper also provides an interesting insight into how context determines social entrepreneurship in KP, Pakistan.
\end{abstract}

Keywords: women social entrepreneurship; institutional theory; feminist theory; sustainability; context based; enablers; constraints; developing country

\section{Introduction}

Today, many women contribute to government, business, and politics. Recently we have also seen a rapid expansion of the number of female entrepreneurs. Yet, in some developing countries, women face enormous challenges in trying to accomplish their entrepreneurial dreams. Pakistan is the sixth most populous country in the world, and almost half of its population is women. It presents exemplary cases of women struggling with challenges of dynamic modernization, heritage, and conviction. Like other developing countries, in Khyber Pukhtunkhawa (KP), Pakistan, female entrepreneurs do not enjoy the same opportunities as men. Women are often thought best suited as "home makers" rather than being breadwinners. They are encouraged to stay at home and refrain from indulging in such pursuits. However, a small number of women still start entrepreneurship ventures; some have social objectives in mind. For these women, the dynamics of the context create interesting enablers and constraints for managing a business in Pakistan. 
This perspective informs our research problem: which theory best explains this situation? We try to bridge the practices of social entrepreneurship with theory as it applies to the small but expanding number of women engaged in social entrepreneurship. After a review of the relevant literature, this research presents an exploratory study critically examining a sample of female social entrepreneurs in Peshawar, KP, Pakistan. Drawing on novel empirical evidence, we explored the motivation, entrepreneurial enablers, entrepreneurial practices, and local and cultural factors that are impeding the growth and development of female social entrepreneurs in KP Pakistan, i.e., within the context of a developing country. We conducted interviews with female social entrepreneurs, focusing on their entrepreneurial journey. We were particularly interested in the factors that motivated them towards social entrepreneurship. These factors are embedded in their life stories and are influenced by their contextual realities. This led us to collect interviews as life stories and entrepreneurial journey narratives.

Female entrepreneurship has attracted considerable attention around the globe, and has developed a substantial literature [1-4]. Female entrepreneurship is a growing phenomenon [1,4,5], recognized as contributing economically in terms of growth and job creation [6-8] and for improving quality of life [8,9]. Female entrepreneurship is also recognized as a source of entrepreneurial diversity. Nevertheless, their talents and potential often remain untapped in developing countries such as Pakistan, due to economic and socio-cultural complexities $[1,10]$. Research has emphasized that there are only a limited number studies concerned with the contextual environment for entrepreneurship [11-13]. Yet, trying to understand in isolation without considering context presents a limited insight $[4,14]$. Therefore, we believe it is important to attend to the social constructions of gender in this context, yielding new insights into theory and perspectives of entrepreneurship [15]. Our core argument is that understanding gender in the context of entrepreneurship is necessary to understand entrepreneurial behavior, such as how they respond to entrepreneurial enablers and constraints.

This study takes full account of context, identifying gender bias gaps identified by the literature, especially Feminist theory $[4,13,16,17]$. Our empirical analysis of women's entrepreneurial journeys is theoretically contrasted with current theory.

\section{- Context and Social Entrepreneurship: A complementary understanding from Institutional and Feminist perspectives}

The term "Social Entrepreneurship" cannot be defined or understood properly unless one understands the word "Entrepreneurship" and "social". Martin and Osberg [18] defined entrepreneurship as "the combination of a context in which an opportunity is situated, a set of personal characteristics required to identify and pursue this opportunity and the creation of a particular outcome". The word "social" then modifies the term. Entrepreneurship driven by altruism rather than by money or profit is termed "social entrepreneurship". A social entrepreneur is argued to be strongly motivated by pursuing their vision relentlessly for psychic rewards [18]. Social entrepreneurs seem to aim for value in the form of transformational benefits. Such transformation in society leads to major significant positive changes in social, political, and economic contexts for marginalized areas like KP, Pakistan. But contexts vary in how they affect entrepreneurship $[14,19,20]$. However, North provides us with a useful theoretical account of how context works in formal and informal institutions. Institutions provide the general rules of the game which facilitate social, political, and economic interactions [21-23].

Building on the above discussion, to understand social entrepreneurship, one cannot neglect the significance of the context in which it takes place. Entrepreneurial behavior is embedded in its context [24]. Uniqueness of the context can result in unique entrepreneurial behavior, thus challenging the explanatory power of existing theories. Merely describing and considering entrepreneurs in isolation without considering context offers a limited understanding of entrepreneurship $[4,12,19]$. This seems to suggest the need for a contextual approach towards social entrepreneurship. Understanding context requires exploration of what determines a particular context. Institutions consist of rules of the game (formal and informal) [25]. Entrepreneurs act within a context determined 
by these rules [23], but formal and informal institutions are not independent, nor are they immutably fixed; they tend to interact. Accordingly, changes to the fundamental constitution of formal and informal rules of the game can result in either enabling or constraining entrepreneurship.

The literature on female entrepreneurship and institutions is still considered fragmented $[15,26]$. Institutional theories fall into three different categories. These categories, i.e., cognitive, normative, and regulatory, describe, as their names suggest, different functions of institutional application. The cognitive institutions "represents models of individual behavior based on subjectively constructed rules and meanings that limit appropriate beliefs and actions" [27]. Considering the gendered context of $\mathrm{KP}$, the cognitive religious institutions are powerful, thus challenging the way residents look at gender [28]. Institutional theory works well to explain the context, formal, and informal institutions in detail, yet it fails to present a clear perspective on the gendering of these contexts. Institutional theory informs us about the structure of the society. Hence, for our purpose of explaining enterprising activities, we treat feminist theory as institutional theory. Put differently, these theories try to explain the "position" and role of women in society. Therefore, the inclusion of feminist theory for understanding the gendering of these institutions, and ultimately, the context is vital [15]. We focus on how gendering is seen, and how it influences entrepreneurial behavior. We argue that entrepreneurs are not the only ones who are gendered; the socio-cultural context in which entrepreneurship is taking place can also be gendered [29]. Put differently, different contexts are deemed to be more appropriate for masculine practice. The issue of how entrepreneurs are constrained and enabled by the environment in which they live and work has been studied in the light of institutional theory by researchers like Scott [30], Bruton and Ahlstorm [27], and Gaddefors and Anderson [19]. Feminism looks at the world through the lens of gender, not women or femaleness [31], but sees how gender is institutionalized. Consequently, we argued that the ways in which gender is understood re significant for understanding entrepreneurship research and practice $[16,17]$.

Our analytical conceptual framework offers a multi-level research lens for understanding female social entrepreneurship in eastern developing country context. This framework (Figure 1) combines institutional and feminist theory in order to clarify how these theories can be used in combination to enhance clear understanding of social entrepreneurship with respect to context.

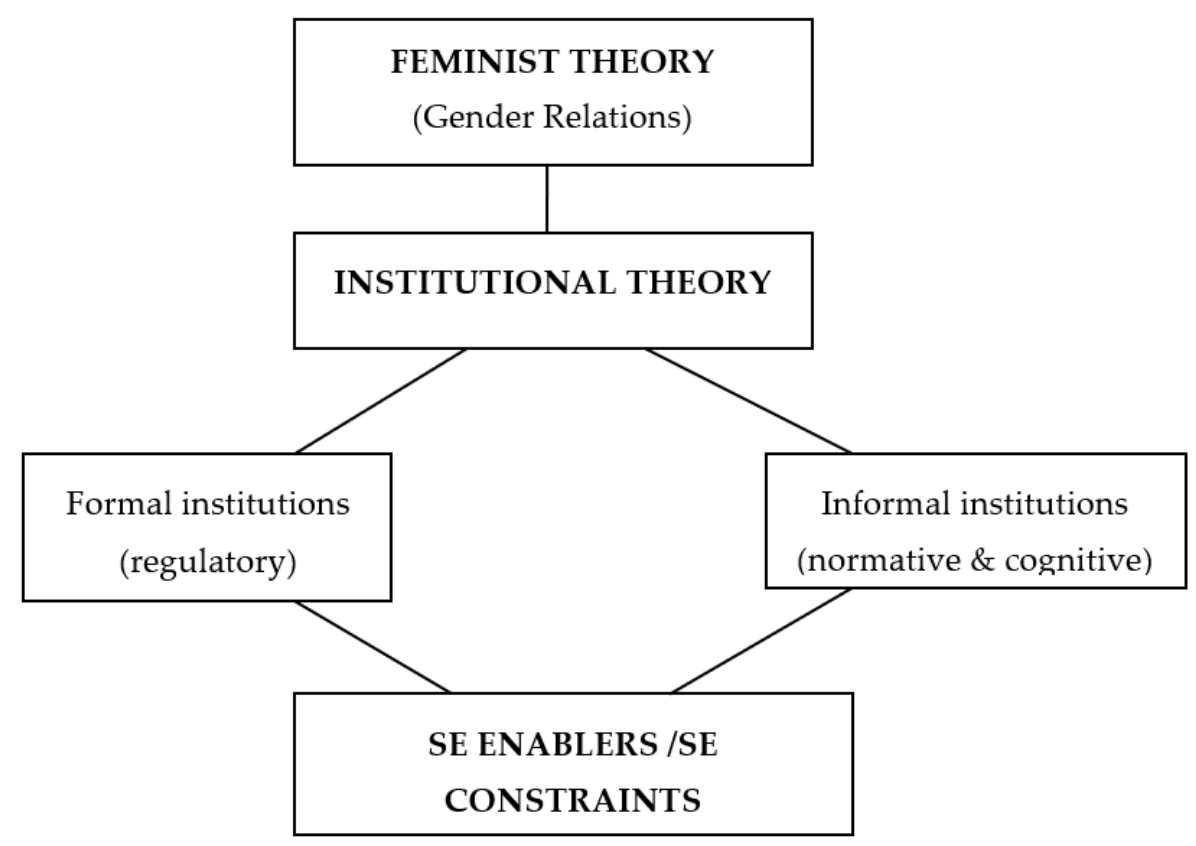

Figure 1. Conceptual Framework Adapted by $[4,15,21,23]$. 
We posit that the framework synthesized in Figure 1 is very powerful in analyzing the female social enterprise in developing country like KP Pakistan, because it recognizes the complexity of social systems through a multilevel institutional and feminist lens. To study entrepreneurship, we acknowledge that we are studying gendered beings (sample) in a gendered context, which is consistent with the recent work in the study of social entrepreneurship $[4,15,26,32,33]$. We adapted a conception of the female entrepreneurship as forming around or anchored in a specific context. Conception and orientation is important to understand the dynamics of entrepreneurship in any given context [34]. Thus, we understand social, and indeed all, entrepreneurship as socially situated [35]. Our analysis worked around North's distinction between formal and informal institutions, which provides a useful insight into societies in which entrepreneurship takes place [36].

Informal institutions are composed of rules and standards to which an individual is expected to conform. Such rules also encourage or discourage entrepreneurial behavior (emergence of S.E) $[20,24,37]$. It also limits the entrepreneur's beliefs and actions because non-compliance to informal rules can result in bad reputation and lack of acceptance in the community [38], and the social legitimacy of a practice or behavior is challenged [28]. As such, informal forces shape the standing of an entrepreneur in a society. Regulatory forces on the other hand deal with formal mandatory rules which, if refused, can result in formal sanctions [24-35,37]. Together, these institutional forces deal with the implementation of social entrepreneurship.

Rethinking categories like man, woman, context/area, and entrepreneur become crucial to understand entrepreneurship as a situated practice. Pakistan, particularly $\mathrm{KP}$, is set in a strong feminist patriarchal culture which strongly influences the societal structure (institutions), materializing as the institutions of this area. Entrepreneurship being constrained and enabled by the environment has been acknowledged by many researchers in the past such as Scott [30] and Bruton and Ahlstorm [27]. Figure 1 builds on this notion of feminist theory. It proposes that feminist geographies provides an adequate framework within which one can study how gender is shaped in a given place/context and vice versa, and how it relates to structuring society and entrepreneurship. From this, we tried to derive a deeper clarity into understanding female social entrepreneurial behavior in a developing-country context, and how it's influenced by the salient institutional and feminist pressures that are at play.

\section{- About the Context of KP, Pakistan \& the Situation of Women}

Pakistan is a South Asian country with $96.4 \%$ Muslim population. Notably, $49.2 \%$ of the total population is women. In addition, $15.42 \%$ of the total population belongs to the Pukhtun community of KP province of Pakistan, which is one of the four administrative provinces of Pakistan. Women in the traditional Pakistani culture are considered as homemakers and custodians of family honor. In countries like Pakistan, the impelling societal norms and conservative practices are widespread. The legislation of Pakistan follows Islamic principles, but social setting is often influenced by pre-Islamic tribal trends $[39,40]$ that promote patriarchal culture, thus ensuring women are structurally subordinate to men. These cultural norms give men control of women's lives, so that gender forms an organizing principle for Pakistani society. Tradition and conservative social values construct the gender-role expectations in Pakistani society [41,42]. This construction is primarily based on the concept of reproduction and production, as perceived and feminine masculine traits [43]. Consequently, the social value of gender is predetermined by the patriarchal values that are embedded in local traditions and culture in Pakistani society. Such a division has placed women in reproductive roles in the private arena of home, while men are considered as the breadwinners in the public arena [44]. Pakistani women are disadvantaged by this entrenched social evaluation. Their social status is low, reduced to roles as producers and providers. Men are provided with better education and skills, while women are only endowed with the domestic skills to be useful at homes. This treatment leads to the economic and social dependency of women in this country [39,44]. These factors are reinforced with the institutional structures of this country which are informed by institutionalized sexism. Such is the gendered culture and context that forms the institutions of our study. 


\section{- Status of Women in KP}

$\mathrm{KP}$ is grappling "Gendered modernity", where women are no longer willing to tolerate discriminatory social practices and laws, although the conservative mindsets still prevails, blocking the way of many angry, educated women $[40,45]$. Moreover, KP remains very conservative, retaining gender disparity [46]. Among the Pukhtun tribes, the cognitive symbols of the Islamic religion are very important and clearly visible. These symbols allocate status, and measure religiosity of the people within Pukhtun society. The reluctance to give women the power to exercise their rights, and to seek employment instead of staying at home, to become financially independent, or even to work among men, demonstrates the close conformity with religious informed traditions. Indeed, conservative religious groups are aggressively promoting restrictive gender norms which relegate women to domestic roles [45]. These socialized norms are compounded by entrenched gender differences, according to Government of Pakistan Bureau of Statistics [47] the general population literacy rate (Table 1) is $36 \%$ for women and $72 \%$ for men in KP. Low literacy levels, patriarchy, women's lack of access to information, knowledge, and employment due to restricted mobility make progress for women very difficult $[45,46]$. Women in Pakistan mostly remain confined to the home and are excluded from any decision making [48].

Table 1. Literacy Rate.

\begin{tabular}{cccc}
\hline 2015-2016 & Total\% & Male\% & Women $\%$ \\
\hline Literacy Rate in KP & 53 & 72 & 36 \\
\hline Rural & 50 & 70 & 33 \\
\hline Source Link: http://www.finance.gov.pk/survey/chapters_17/Pakistan_ES_2016_17_pdf.pdf.
\end{tabular}

\section{KP Women as Entrepreneurs}

Small and medium business provide major employment in Pakistan; however, entry into these businesses is still difficult with low added value products [28]. In addition, there is a notable gender gap in small starts ups and ownership of SMEs. For instance, GEM data from 2012 indicates a gender gap in Pakistan. For instance, early stage entrepreneurial activity rate is lowest in the region (1.2 for women as compared to 21.27 for men). The gap is very obvious in ownership structures (1.60 for women and for men 5.81). This gender gap creates hurdles and barriers in economic development [28]. In a relatively recent survey, the labor force survey by the Government of Pakistan [47] showed that female entrepreneurial activity level is only $0.1 \%$. This tiny participation rate suggests that the factors discussed earlier, and their influence on women's power and mobility, create formidable challenges for female entrepreneurship. One response is that female entrepreneurs in KP mostly engage in textiles, garments, food, and jewelry, or provide beautician services. Moreover, they often work through undocumented channels (informal entrepreneurship) due to the unfavorable entrepreneurial environment. Indeed, most even lack knowledge about the formal channels of entrepreneurship. Furthermore, constraints such as male-focused credit allocation, difficulty in dealing with licenses, registering or acquiring property, and working outside of their homes add to women's disadvantages [45]. A study conducted by USAID [49] showed that Pakistani women, especially in $\mathrm{KP}$, are rarely on the boards of industrial organizations. This translates into fewer opportunities for partnering, networking, and identifying opportunities. We conclude that KP's culture, norms, and values are hostile to female enterprise. Consequently, our objective is to understand this context in order to fully appreciate the mechanisms for establishing successful female entrepreneurship. 


\section{Methodology}

Our study is qualitative and employs an interpretive framework [50].

Data collection took 19 months, during 2016-2017, and purposive sampling was deployed. This technique allows a researcher to critically select cases that relate to the objectives of the study. It involves identifying and selecting appropriate respondents who are well informed about the phenomenon under study $([51,52]$ p. 370). Our sample consists of entrepreneurs who are small scale, micro-social entrepreneurs, but who seem to be making a difference to social wellbeing.

We held 10 in-depth, one-on-one interviews with these successful KP female social entrepreneurs. These ten cases appeared to be critical cases among others we had considered. Our selection criteria were based around these being 'interesting' cases. By interesting, we mean that they seemed potentially theoretically rich, offering useful examples of the phenomena; a theoretical sample [53].

As discussed earlier, KP women face constraints and barriers from several different angles. This means that these 10 social entrepreneurs are interesting because they challenged social norms in both their practices and in what they tried to achieve. They offered examples of a duality of challenges; in what they did and how they did it, but also in their outputs. Yet, they also seemed to manage (Table 2). Our semi structured interview protocol was comprised of open-ended questions grouped into themes (Figure 2). The interviews took between 50 and $160 \mathrm{~min}$, were conducted in Urdu and Pashto, and were recorded. The recordings were later translated into English by one author, and checked by another to ensure accuracy. These data were then categorized and analyzed thematically. Our findings are consolidated in a model of female social entrepreneurial enablers, constraints, and challenges.

The businesses operated within traditional sectors such as textiles, education, beauty, vocational training, and food. All of the participants are well educated. Most (90\%) concentrated on the service sector and had predominantly female customers (Table 2). This structure reflects the social norms which are typical of Islamic countries [54]. They operate in such areas where male-female interaction is minimized (education, food sector) or almost non-existent (Health and beauty, vocational trainings). Their entrepreneurial choices are thus context specific, and the data shows that context determines entrepreneurial choices.

The data were analyzed through thematic analysis [55], which is a widely accepted approach for studying entrepreneurial situated practices [56], and is appropriate for interpretative studies [57,58] Thematic analysis involved specific steps: (1) Getting fully familiar with the data through thorough reading and re-reading interview transcripts; (2) Categorising and coding the material; (3) Identifying themes (Table 3 presents the codes and themes identified); (4) Identifying explanatory connections, 5. Theorising, or explaining, the how, what, and why of their entrepreneurial practices. 
PERSONAL INTERVIEW GUIDELINE

\section{Pre-Interview checklist on interview day}

- Reconfirmation of interviewee availability of time and date via phone call

- Stationary and recording device

- Mapping of location

\section{Organization}

XYZ

Name of Respondent

$\mathrm{ABC}$

Meeting Time and Date

Meeting Location

\section{During Interview}

Icebreaking

- Introduction of researcher and project

- Ask introductory questions from interviewee

- Agreement on expected time and inform interviewee of conditions of confidentiality

- Ask permission for use of tape recorder

\begin{tabular}{|c|c|c|}
\hline Interview Themes & Subtopics & Notable Points \\
\hline Drivers & $\begin{array}{l}\text { What are the motivation factors that motivated the } \\
\text { respondent towards social entrepreneurship, why } \\
\text { social entrepreneurship, what drives the respondent } \\
\text { towards being social }\end{array}$ & \\
\hline Issues \& Challenges & $\begin{array}{l}\text { What kind of issues and challenges the respondents } \\
\text { are facing, why are they facing these issues and } \\
\text { challenges, what are they doing about it, and how } \\
\text { are they responding towards them. Probe to relate } \\
\text { with institution environment with examples }\end{array}$ & \\
\hline Barriers & $\begin{array}{l}\text { What kind of barriers social entrepreneurs of KP } \\
\text { are facing, how they are hindering the respondents } \\
\text { capabilities, how can they overcome these barriers, } \\
\text { clarification of terms and respondents answers }\end{array}$ & \\
\hline
\end{tabular}

Post Interview

- Offer to review transcription of interview and findings of research after completion

- Email to thank interviewee for their time

Figure 2. Interview Guideline. 
Table 2. Interviewee List (Details).

\begin{tabular}{|c|c|c|c|c|c|c|c|c|}
\hline No. & Name & Age & $\begin{array}{l}\text { Marital } \\
\text { Status }\end{array}$ & Education & Type of Business & Source of Start-Up Capital & $\begin{array}{l}\text { Registered/Not } \\
\text { Registered }\end{array}$ & $\begin{array}{l}\text { Years in } \\
\text { Business }\end{array}$ \\
\hline 1 & Mrs. A & Mid-40s & Married & Masters & $\begin{array}{l}\text { Home Based/Service and product Based } \\
\text { (Textiles, education, beauty, vocational } \\
\text { trainings \& food) }\end{array}$ & Sold personal jewelry & Registered & 16 years \\
\hline 2 & Miss B & 23 years & Single & $\begin{array}{l}\text { Bachelor's } \\
\text { Degree }\end{array}$ & Service Based (Beauty Salon) & Mother & Registered & 18 years \\
\hline 3 & Miss C & 28 years & Single & High School & Home Based/Service Based (Beauty Salon) & $\begin{array}{l}\text { Personal savings, saved over a period of } \\
4 \text { years by doing job }\end{array}$ & Not Registered & 7 years \\
\hline 4 & Mrs. D & Mid-30s & Married & Masters & $\begin{array}{l}\text { Home Based/Service and Product Based } \\
\text { (Textiles, Vocational Training) }\end{array}$ & Personal savings, saved by doing job & Not Registered & 8 years \\
\hline 5 & Miss E & 29 years & Divorced & Masters & $\begin{array}{l}\text { Service and product Based (Textiles, } \\
\text { Vocational trainings, education) }\end{array}$ & Sold personal jewelry & Registered & 5 years \\
\hline 6 & Mrs. F & Mid-40s & Married & Masters & Home Based/Service Based (Education) & Personal savings and Husband & Not Registered & 6 years \\
\hline 7 & Miss G & 23 years & Single & $\begin{array}{l}\text { Bachelor's } \\
\text { Degree }\end{array}$ & $\begin{array}{l}\text { Home Based/Service Based (Beauty Henna } \\
\text { Artist) }\end{array}$ & Personal Savings and parents & Not Registered & 4 years \\
\hline 8 & Mrs. $\mathrm{H}$ & Mid-40s & Married & Masters & $\begin{array}{l}\text { Home Based/Service Based (Organic food } \\
\text { service) }\end{array}$ & Personal Savings & Not Registered & 3 years \\
\hline 9 & Miss I & 28 years & Single & $\mathrm{PhD}$ & $\begin{array}{c}\text { Home Based / Service and Product Based } \\
\text { (Online Business, vocational trainings, } \\
\text { education) }\end{array}$ & Personal Savings & Not Registered & 4 years \\
\hline 10 & Mrs. J & Mid-30s & Married & Masters & Service Based (Education) & Personal Savings and sponsorships & Not Registered & 3 years \\
\hline
\end{tabular}


Table 3. From Codes to Basic Themes and Organizing Themes.

\begin{tabular}{|c|c|c|}
\hline Step 1: Codes & Step 2: Basic Themes & Step 3: Organizing Themes \\
\hline $\begin{array}{l}\text { Hobby } \\
\text { Friends } \\
\text { Family } \\
\text { Support } \\
\text { Appreciation } \\
\text { Encouragement } \\
\text { Rejection } \\
\text { Risk taker } \\
\text { Brave } \\
\text { Ambitions } \\
\text { Dream }\end{array}$ & $\begin{array}{l}\text { (1) Importance of Personal ambitions and } \\
\text { risk taking } \\
\text { (2) Importance of support and } \\
\text { encouragement from immediate family }\end{array}$ & $\begin{array}{l}\text { Entrepreneurs personal traits and family } \\
\text { support matters in their success }\end{array}$ \\
\hline $\begin{array}{l}\text { Home makers } \\
\text { Women born weak } \\
\text { Men responsible for earning } \\
\text { Not allowed in islam } \\
\text { Chastity required of women } \\
\text { Practice of pardah } \\
\text { Spatial boundry between men and women } \\
\text { Protect modesty } \\
\text { Custodians of family honor }\end{array}$ & $\begin{array}{l}\text { (3) Women considered weak as compared } \\
\text { to men } \\
\text { (4) Outside home is not a respectable place } \\
\text { for a women } \\
\text { (5) Misuse of religion }\end{array}$ & $\begin{array}{l}\text { Gender inequality-feminist } \\
\text { theory/institutional context }\end{array}$ \\
\hline $\begin{array}{l}\text { Stand on own } \\
\text { Financial independence } \\
\text { Meaning of life } \\
\text { Felt worthless } \\
\text { Do better for less fortuante women } \\
\text { Societies misfortunes } \\
\text { Women can do anything } \\
\text { Prove onesself }\end{array}$ & $\begin{array}{l}\text { (6) Breaking all chains and fighting for one's } \\
\text { position and value in society } \\
\text { (7) Desire to earn and be independent }\end{array}$ & Women Empowerment \\
\hline
\end{tabular}


Table 3. Cont

\begin{tabular}{|c|c|c|c|}
\hline Step 1: Codes & & Step 2: Basic Themes & Step 3: Organizing Themes \\
\hline $\begin{array}{l}\text { Permission of elder male } \\
\text { Parents/husband/In-laws } \\
\text { Societies acceptability important } \\
\text { Respectable job search } \\
\text { In line with society } \\
\text { Family time comes first } \\
\text { Home- women's responsibility } \\
\text { Hard to gain societies/family's trust }\end{array}$ & $\begin{array}{l}(8) \\
(9) \\
(10) \\
(11)\end{array}$ & $\begin{array}{l}\text { Work in line with social norms } \\
\text { Trust issues } \\
\text { Patriarchal culture } \\
\text { Work life balance }\end{array}$ & $\begin{array}{l}\text { Institutional theory-rules of the game in a } \\
\text { society/Standpoint Feminism }\end{array}$ \\
\hline $\begin{array}{l}\text { Taliban rule } \\
\text { Warnings issued } \\
\text { Anti women } \\
\text { Working women not allowed in islam } \\
\text { Women business forbidden } \\
\text { Blasts } \\
\text { Kidnaping } \\
\text { Women education criticised }\end{array}$ & $\begin{array}{l}(12) \\
(13)\end{array}$ & $\begin{array}{l}\text { Security issues/Terrorism } \\
\text { Religious exploitation }\end{array}$ & $\begin{array}{l}\text { Religious extremist's exploitation through } \\
\text { terrosrism }\end{array}$ \\
\hline $\begin{array}{l}\text { Realization } \\
\text { Women uplifting } \\
\text { Help and opportunities } \\
\text { Liberation } \\
\text { Guidance } \\
\text { Need one another } \\
\text { Society improvement } \\
\text { Need reforms } \\
\text { Together }\end{array}$ & $\begin{array}{l}(14) \\
(15) \\
(16)\end{array}$ & $\begin{array}{l}\text { Entrepreneurs realized the need for } \\
\text { societal reforms for women liberation } \\
\text { Entrepreneurship resulted in women } \\
\text { uplifting in society } \\
\text { Provides women with opportunities to } \\
\text { grow in a given context }\end{array}$ & Social Entrepreneurship as emancipatory \\
\hline $\begin{array}{l}\text { Bribery in Government institutions } \\
\text { Institutions not efficient in their task } \\
\text { Rules are difficult } \\
\text { Law not flexible for women } \\
\text { Challenge for women }\end{array}$ & $\begin{array}{l}(17) \\
(18) \\
(19)\end{array}$ & $\begin{array}{l}\text { Government institutions lacks } \\
\text { honesty and dedication } \\
\text { The government institutions are not } \\
\text { efficient in the tasks }\end{array}$ & $\begin{array}{l}\text { Bureaucracy as constraint/Institutional } \\
\text { corruption }\end{array}$ \\
\hline
\end{tabular}


Table 3. Cont

\begin{tabular}{|c|c|c|c|}
\hline Step 1: Codes & & Step 2: Basic Themes & Step 3: Organizing Themes \\
\hline $\begin{array}{l}\text { Medical/teaching respectable options } \\
\text { Business education not for women } \\
\text { Un awareness of marketing/market } \\
\text { Finanical dependant } \\
\text { Middle class } \\
\text { Limited due to resources }\end{array}$ & $\begin{array}{l}(20) \\
(21)\end{array}$ & $\begin{array}{l}\text { Lack of business education } \\
\text { Scarcity of resources }\end{array}$ & $\begin{array}{l}\text { Women lack independent resources, education } \\
\text { and basic awareness about laws }\end{array}$ \\
\hline $\begin{array}{l}\text { Government support programs almost nil } \\
\text { No awareness programs } \\
\text { Lack understanding of law } \\
\text { Need supervision } \\
\text { Need of understanding SME's in pakistan } \\
\text { Major issues faced } \\
\text { Commercial and residential area issue-major }\end{array}$ & $\begin{array}{l}(22) \\
(23)\end{array}$ & $\begin{array}{l}\text { Lack of awareness about rules } \\
\text { and regulations } \\
\text { Lack of support from government }\end{array}$ & Rules and regulations are complicated \\
\hline $\begin{array}{l}\text { Vocational trainings provided by NGO } \\
\text { Jobs provided by NGO } \\
\text { Motivates } \\
\text { Earning a living } \\
\text { Awareness of self-worth } \\
\text { Helps financially and emotionally }\end{array}$ & $(24)$ & $\begin{array}{l}\text { Women driven NGO sector supports } \\
\text { women empowerment }\end{array}$ & NGO sector's dedication appreciated \\
\hline
\end{tabular}




\section{Research Findings}

We found that a strong need of achievement and independence, and a desire to transform society for the betterment of women, were the key enablers to opt for social entrepreneurship, as is systematically explored below in Table 4 . The analysis demonstrated that the participants engaged in entrepreneuring self-actualization to achieve financial independence and female status recognition. They were motivated to change the way society looks at working women.

Mrs. A states,

"We are living in 21st century, a century of advancements and opportunities, where women have even gone into the space, whereas in KP Pakistan seeing a woman driving on the road is still a surprising view for us". The respondent here is trying to explain the gravity of the situation by comparing it to the developed world. Even with general female advancement, our respondents are struggling and fighting for their human basic rights.

Female structural subordination to men in KP is clear from the data analysis. Baugh, Chua \& Neupert [59] found evidence that gender inequality acts as an inhibitor for ones growth and development. It hinders opportunity and choices, or can even prevent them arising. Such inequality can be described through an institutional context $[45,59]$. Such subordination and the inclination to deny women their rights have been blamed on unrealistic religious propositions [60] by the KP society. In different, less conservative interpretations, Islam has given women the right to pursue knowledge and education, to own property and businesses, to hold any office, even political, and to enjoy equality, honor, and respect [61]. 'True' interpretations of the status of women need to be fostered in order to bring about positive change in this society [60]. Religious extremism and fundamentalism is used interchangeably, but Pratt [62] argues that "Extremism suggests fanaticism". This seems to be the case in KP. During the last decade, terrorists groups have indoctrinated people with radical islam, causing serious security issues. Such extremists have continuosly targetted empowered women. The data analysis shows radical islam as a prominent explanatory institutional theme. Such religious exploitation and terrorism have constrained female entrepreneurs of KP, Pakistan. Yet, the data also demonstrates the courage of KP women who chose not to be intimidated by these groups. Instead, they fought for their rights, even when their lives were threatened. Several respondents also refered to how institutional corruption had detrimentally affected their efforts. Table 5 presents the constraints/barriers themes found in the data in the participants' own words.

Kabeer in [63] argued that the empowerment of women comprises bestowing the "ability to make choices" (p. 436). The data shows that women in KP society mostly lack the "ability to make decisions", because of the patriarchal structure of the society. Nonetheless, five of the respondents enjoyed immediate family support, which had a strong influence over their success. Two others had immediate family support, but they believed that this was because their immediate family consisted only of women (mother, sisters). They explained that when the male head of their family was alive, they lacked approval to work. Feminism advocates the rights of humans on the grounds of equality of the sexes. This appeared to be the case in three extreme cases where the respondents simply chose to ignore the constraints and opt for a "don't care"(Strategies of avoidance) approach. Table 5 presents a view of that approach in respondents own words.

Another recurring strong theme in the data was the dedication and effectiveness (Collaboration) of the NGO sector of KP. The majority of interviewees greatly appreciated the role of the NGO sector, and ranked it as much better than government support for female social entrepreneurs. The interviewees stated that the NGO sector has been a blessing for them, and that they have learnt a lot through working with it. 
Table 4. Themes in the Interview Data.

Enablers

Financial Independence

Women status recognition/empowerment emancipatory

\section{Explained through Interview Raw Data}

"I am thankful to my ex-husband and in-laws for their treatment because that motivated me to look outside of my own world." (Miss E)

"So I decided not to take any further financial help from my family. I decided to create an example of myself that single mothers of the society could reflect upon. I had 8.5 million (8500 Dollars) worth of jewelry at the time of my wedding, out of which 7 million (7000 Dollars) worth jewelry was taken by my mother in law on my wedding day claiming that it's a custom in her family, thus I was never able to recover that jewelry. I sold the rest 1.5 million (1500 Dollars) worth jewelry after my separation and invested that money in my aunt's ladies' gym." (Miss E)

"An insight that is crucial to my success and to the development of women in the region has been the idea that education, training and self-development is the birth right of each individual and it is to be shared amongst all and not to be sold or kept hidden." (Miss B)

"I personally believe that women should work apart from managing home, and they should be financially empowered. I believe this financial independence is important for women so that's why I wanted to work on it." (Mrs. J)

"My husband did not allow me to do job, Because of family pressure. I always felt that I need to be more than just a house wife. I was passionate about becoming financially independent and wanted to do more than house hold work". (Mrs. A)

"Apart from friends and family, financial independence was also another reason that motivated me towards this journey" (Mrs. A, Mrs. D)

"Because I personally believe that women should work apart from managing home, and they should be financially empowered. I believe this financial independence is important for women so that's why I wanted to work on it. Education and independence, financial independence, as I said I strongly believe in economic

empowerment of women, because these things give one confidence to believe in oneself. Such independence makes you realize that no matter what happens, no matter what people say you are able to survive." (Mrs. J, Miss B)

"Historically, women in KP have had a relatively restricted role in shaping public life and all institutions that serve public needs are administered and lead by men. Even in the arena of free enterprise the symbol of a working man reflects passion, endurance and innovation and women are rather encouraged to lay dormant and refrain from indulging in such pursuits. Hence women rarely ever develop social connections that would lead them into entrepreneurial-ship more so because of the restrains posed by a patriarchal society and not due to a lack of initiative on women's part. In fact the story of B's challenges a prevailing view that there is lack of opportunity for women, and that women ought to refrain from participating in free enterprise within a male dominated society". (Miss B)

"it's always a journey so exactly I cannot say where did it start but I always had this in mind that I want to do something for society so that was always there." (Mrs. J, Mrs. A, Miss C)

"I found it challenging to start my own independent business in KP as a woman, because it was against the Pukhtun culture and norms, but I made this brave and courageous decision that young women could reflect upon." (Mrs. A)

"Hence I decided to help the local women by providing relevant skills to become independent and earn on their own and I knew I could help in changing women image in the KP society." (Miss. E, Miss C)

"I would say that I started this because I wanted to create good citizens for society, Citizens with ethical and civic sense. My aim isn't to create just doctors or engineers as other institutions but to create a good society, People who have civic sense and are able to help others when they are able. We give them education about lying, stealing and bad habits like that. We teach them what's right and what's wrong." (Mrs. J, Mrs. F) 
Table 5. Themes Explained Through Interview Data.

\begin{tabular}{|c|c|}
\hline $\begin{array}{c}\text { Constraints/Barriers } \\
\text { Themes }\end{array}$ & Constraints/Barriers Explained Through Participant Interview Raw Data \\
\hline Resources & $\begin{array}{l}\text { "The financial situation got much worse after the death of my father. In our society orphaned girls are considered to be a burden and are discouraged. There are made } \\
\text { to realize that need the support of a "strong pillar" to move forward in life. To support the needs of the family and to pursue my dreams with all these problems is not } \\
\text { easy especially during the time of high inflation in the country". (Miss. C) } \\
\text { "I could feel the situation of their lives and I wanted to help. I want to do a lot more for them but I don't have the resources". (Miss. C, Mrs. J) } \\
\text { "I had financial problems in the start but I couldn't ask anyone due to self-respect." (Mrs. A, Miss. E) }\end{array}$ \\
\hline $\begin{array}{l}\text { Religious } \\
\text { Extremism }\end{array}$ & $\begin{array}{l}\text { "In 2012, I received a letter from the Taliban (Terrorist groups working in Pakistan at that time). In the letter I was threatened to close my Training Academy soon } \\
\text { otherwise there will be serious consequences. They stated that my work and my academy are against the very principles of Islam and it dishonors the religion so it } \\
\text { must be closed down otherwise they will blow the academy (Bombing)". (Mrs. A) } \\
\text { "My father was kidnapped by the Taliban (Terrorist group) in order to stop us from our work." (Miss B) } \\
\text { "Due to APS incident (130 students shot in school by terrorists), the parents were scared to send their children to schools. It also creates constraints for us in terms of } \\
\text { security related issues." (Mrs. F) }\end{array}$ \\
\hline $\begin{array}{l}\text { Immediate Family } \\
\text { unsupportive }\end{array}$ & $\begin{array}{l}\text { "My husband also doesn't like my business. He is not supportive about it. According to him I should spend my time to look after my home and children as that is my } \\
\text { main responsibility". (Mrs. H) } \\
\text { "Being a topper and a position holder in my school, I was forced by my elders to opt for medical as according to them, a student as intelligent as me should not go for } \\
\text { arts. I was always interested in Painting and Baking but my elders never allowed me to go for these fields. Such pressures increase further if a daughter doesn't have } \\
\text { her father beside her". (Miss I) } \\
\text { "Then I observed that in the living colony that I live, some of the parents of the girls won't allow them to go out of the house. Even for education. Even after some } \\
\text { primary education of class 1, } 2 \text { and } 3 \text { they would make them sit at home" (Miss G) }\end{array}$ \\
\hline $\begin{array}{l}\text { Institutional } \\
\text { Corruption/ } \\
\text { Bureaucracy }\end{array}$ & $\begin{array}{l}\text { "The tax department also created difficulties for me. Most of the tax department employees demand bribes in order to stop creating difficulties." (Mrs. A, Miss C, } \\
\text { Mrs. F) } \\
\text { "The things that needed to be taken care of outside which men can handle in our society. It's difficult for a woman to go out and go to different places and government } \\
\text { offices to get things done. Weather big or small. So, you need a man to go out and solve these problems. I still cannot figure out that all these schools still running in } \\
\text { residential areas, how are they still operational" (Mrs. F, Miss C) }\end{array}$ \\
\hline Confused Systems & $\begin{array}{l}\text { "PDA (Peshawar development authority) sent us notices to move to commercial area within one month otherwise we will be penalized. I have been operating in } \\
\text { residential area for the last } 16 \text { years, and now they realize that I am doing something illegal." (Mrs. A) } \\
\text { The problem with PDA was reported from } 60 \% \text { of the participants. They also argued that this isn't right as in KP women's do not easily get permission to work } \\
\text { outside of their homes due to societal and cultural barriers, and now they cannot in residential area due to legal issues. (Mrs. A, Miss B, Miss C, Miss E, Mrs. F) }\end{array}$ \\
\hline
\end{tabular}


Table 5. Cont.

\begin{tabular}{|c|c|}
\hline $\begin{array}{c}\text { Constraints/Barriers } \\
\text { Themes }\end{array}$ & Constraints/Barriers Explained Through Participant Interview Raw Data \\
\hline $\begin{array}{c}\text { Lack of } \\
\text { Government } \\
\text { support }\end{array}$ & $\begin{array}{l}\text { Only two participants reported government support. (Mrs. A, Miss F) } \\
\text { The rest had support of NGO's operating in KP. }\end{array}$ \\
\hline $\begin{array}{l}\text { Cultural/Societal } \\
\text { Barriers }\end{array}$ & $\begin{array}{l}\text { "Being a young single working mother in a Pukhtun society is the worst situation of all and has a certain stigma attached to it. In such society divorce is associated } \\
\text { with dishonor and shame". (Miss E) } \\
\text { "of course because of the conservative mindset of our society. People think that those who appear on media or work outside homes are not good women". (Miss E, } \\
\text { Miss B) } \\
\text { "My relatives make fun of me and my work. They constantly try to demotivate me. they think that I should be a house wife and refrain from such ventures". (Mrs. H) } \\
\text { "We are living in } 21 \text { st century, a century of advancements and opportunities, where women have even gone into the space, whereas in KP Pakistan seeing a woman } \\
\text { driving on the road is still a surprising view for us". (Mrs. A) } \\
\text { Almost } 80 \% \text { of the participants reported cultural societal issues as constraints. }\end{array}$ \\
\hline
\end{tabular}




\section{Discussion of Findings}

Female entrepreneurship is a maturing field of enquiry. In particular, understanding the role of the institutional environment and the ensuing gendering of roles is rapidly advancing in the literature. This deepening of knowledge has resulted in a solid theoretical foundation for understanding female enterprise. Our findings are consistent with several recent streams of entrepreneurship research that have suggested the usefulness of a multi-level research design $[1,4,15,26,45]$. Our focused research questions centered on the identification of enablers and constraints faced by female entrepreneurs in Pakistan. The respondents' entrepreneurship was studied from an institutional and feminist perspective embedded in its context. Consequently, the respondents' experiences allowed us to build an informed account of the impact of institutions, and also to be able to describe how and why some women overcame the constraints. Previous research $[10,40,60,64]$ has shown that institutions present difficulties for entrepreneurs, but the literature on the reasons for such difficulties is fragmented. Due to the multi-level research framework, we were able to identify reasons for such difficulties within the context of a developing country. This framework allowed us to identify the role of the institutions at play, which would not have been possible without treating institutional theory as feminist theory. The findings show that these difficulties arise because both institutions and female entrepreneurs are conflicted about their roles, as the theme "Confused systems" suggested. The women want institutions to treat them equally with men. Formal institutions adopted the rules of equality and formally treat everyone similarly. However, Informal institutions construct a different and constrained perspective towards women, relegating them to subordination. In the presence of the strong value of traditional norms, religion, and culture in KP, Pakistan, the liberal state of formal institutions becomes questionable, and is rarely applied in practices. This creates difficulties for female entrepreneurs, as they cannot enjoy the liberty of formal institutions due to the strength of the informal institutions, resulting in greater difficulties and conflicting roles.

Religious extremism, and a lack of resources and family support were also found as constraints, thus showing consensus with the findings of Rehman \& Roomi [10], Roomi \& Parrott [60], Mahmood, Sohail, Khalid \& Babak [42], Pakeeza, [39]. A consequence is the power of gendered informal institutions and their influence upon these female social entrepreneurs. Moreover, this is compounded as religious extremists target women and create further hurdles to be overcome. Moreover, family support is crucial for their existence as entrepreneurs, which is not the case for the opposite gender. Treating these cases through feminist theory highlighted the hold of gendering within both formal and informal institutions, such that its importance cannot be ignored. The findings also highlight the problem of institutional corruption in Pakistan as a barrier to entrepreneurship development. Dvoulety and Blazkova [65] similarly acknowledged corruption as a potential barrier to entrepreneurship within the context of a developing country. Here, we saw that even corruption was gendered. Government officials took advantage of female entrepreneurs because they were aware of their subordinate and fragile situation. Furthermore, they were aware of the entrepreneur's lack of awareness about rules and regulations, which led them take advantage of the situation. Due to such institutional constraints, female entrepreneurs face a lot of hurdles which challenge entrepreneurial sustainability in the long run.

Welter and Smallbone [24] argue that entrepreneurs may react to institutional pressures in different ways. The findings of this study suggest that such institutional pressure has led female entrepreneurs towards self-actualization, which has resulted in becoming one of a strong entrepreneurial enabler. Women opted for social entrepreneurship because they saw it as a way out, towards liberation and independence, and it emboldened them to challenge deeply-embedded societal structures. It presented hope for them and provided them with an opportunity to bring small but effective change. Moreover, all of the respondents were committed to helping other women in their society. They are committed towards changing women's standing in society. Although this informal micro entrepreneuring seems to be novel, because we see the purpose of the enterprising as social value creation, we believe the respondents to be social entrepreneurs. Independence, motivation to bring change, and the 
empowerment of women were also found as female entrepreneurial enablers, similar to the study of Roomi [10], Jamali [1], Mahmood et al. [42]. The results of this study may be useful in places with similar institutional climates. It also uniquely specifies the entrepreneurial experience within the context of a developing country, more specifically, within Muslim countries.

\section{Conclusions}

This research has presented a novel insight to cultural power of gender and the gendering of women's roles and expectations within the context of a developing country, both theoretically and empirically. The research captured the interpretive accounts of female social entrepreneurs in the dynamic interplay of institutional and feminist theory to establish the role played by gender, thus developing logic through reconciling predictions from these two theories. Here, we also see a different role to entrepreneurship, i.e., as challenging established social norms. The findings suggest that this form of entrepreneurship is novel; we see the purpose of entrepreneurship as social value creation. Entrepreneurship played a liberating role for women in the context of KP. Furthermore, it made them realize their strengths and value, and provided them with hope for change. We have tried to capture a realistic account of the factors at play that acknowledges the struggle of the women of KP. This research also provides an example of the usefulness and need of an integrated framework reflecting the embeddedness of female social entrepreneurship into its context. Opportunity identification (enablers) lies in the personal characteristics of entrepreneurs, such as resilience, self efficacy, financial independence, autonomy, passion about changing womens status, and the empowerment of women. These characteristics were nested in the contours of their lives. We were also able to isolate such opportunities and constraints, and explored concepts such as role conflicts, gender, gender inequality, and feminism. It was observed that despite the constant societal pressures and tight structures, the entrepreneurs persisted in continuing their journey and work on new ventures that could create positive change in a society such as KP.

Future studies can target the research problem of how entrepreneurs strive for survival in conflicted environments. Studies can also focus on the different reactions of entrepreneur's towards context-related opportunities and constraints, and the strategies they use to tackle them in order to present a deeper understanding of entrepreneurial behaviour. Previous studies suggest the need for studies in this particular area $[4,15,26,66]$. This research suggests that KP entrepreneurs opted for strategies of avoidance, negotiation, and collaboration with governmental bodies or NGOs for survival and success, and confirms that entrepreneurs react in different ways to counteract institutional pressures. Future studies might focus on exploring these strategies to further understanding of this phenomenon. Hence, it can be concluded that institutions and gendering play vital roles in shaping female social enterprise in KP, Pakistan. Therefore, institutions combined with gendering may well offer the foundation for a productive general theory of female social enterprise in developing countries.

Finally, this research gives a novel insight into the experiences of female entrepreneurs in KP. It has explored institutional constraints and motivations. However, it is important to understand the limitations of this research. This research is qualitative in nature, with a non-probability sample, so it lacks external validity. Thus, the findings of this study cannot be generalizable to other context. In addition, it was very difficult to access female entrepreneurs, and to find time for interviews due to cultural constraints.

Author Contributions: All the authors have contributed to this manuscript. M.S.Y. conceived and designed the main write-up, provided the theoretical contribution, development of theoretical framework, and analysis. H.H. collected the data, transcribed the data, conceived the basic thematic coding, and contributed to the formatting of the paper while A.R.A. provided conceptual comments and contributed to the papers review.

Funding: This research received no external funding.

Conflicts of Interest: The authors declare no conflict of interest. 


\section{References}

1. Jamali, D. Constraints and opportunities facing women entrepreneurs in developing countries: A relational perspective. Gend. Manag. Int. J. 2009, 24, 232-251. [CrossRef]

2. Langowitz, N.; Minniti, M. The entrepreneurial propensity of women. Entrep. Theory Pract. 2007, 31, 341-364. [CrossRef]

3. McAdam, M. Women Entrepreneurship; Routledge: London, UK, 2013.

4. Martinez Dy, A.; Marlow, S. Women Entrepreneurs and Their Ventures: Complicating Categories and Contextualising Gender; Routledge: London, UK, 2017.

5. Zahra, S.A.; Wright, M. Understanding the social role of entrepreneurship. J. Manag. Stud. 2016, 53, 610-629. [CrossRef]

6. Orhan, M.; Scott, D. Why women enter into entrepreneurship: An explanatory model. Women Manag. Rev. 2001, 16, 232-247. [CrossRef]

7. Audretsch, D.B.; Keilbach, M.C.; Lehmann, E.E. Entrepreneurship and ECONOMIC Growth; Oxford University Press: New York, NY, USA, 2006.

8. McMullen, J.S.; Warnick, B.J. Should we require every new venture to be a hybrid organization? J. Manag. Stud. 2016, 53, 630-662. [CrossRef]

9. Baumol, W.J.; Litan, R.E.; Schramm, C.J. Sustaining entrepreneurial capitalism. Capital. Soc. $2007,2$. [CrossRef]

10. Rehman, S.; Roomi, M.A. Her Family, Household and Entrepreneurial Venture: Using a Life Course Perspective to Make Sense of the Work-Life Choices of Pakistani Women Entrepreneurs. Available online: https://s3.amazonaws.com/academia.edu.documents/31463953/Rehman_and_Roomi_-_ ICSB_Winner.pdf?AWSAccessKeyId=AKIAIWOWYYGZ2Y53UL3A\&Expires=1543802571\&Signature= 77xWhqGCc5t4uwkOhe59d0\%2FWSEM\%3D\&response-content-disposition=inline\%3B\%20filename\% 3DHer_Family_Household_and_Entrepreneurial.pdf (accessed on 3 May 2018).

11. De Bruin, A.; Brush, C.G.; Welter, F. Advancing a framework for coherent research on women's entrepreneurship. Entrep. Theory Pract. 2007, 31, 323-339. [CrossRef]

12. Sambharya, R.; Musteen, M. Institutional environment and entrepreneurship: An empirical study across countries. J. Int. Entrep. 2014, 12, 314-330. [CrossRef]

13. Dvouletý, O.; Gordievskaya, A.; Procházka, D.A. Investigating the relationship between entrepreneurship and regional development: Case of developing countries. J. Glob. Entrep. Res. 2018, 8, 16. [CrossRef]

14. Paul, J.; Hermel, P.; Srivatava, A. Entrepreneurial intentions-Theory and evidence from Asia, America, and Europe. J. Int. Entrep. 2017, 15, 324-351. [CrossRef]

15. Giménez, D.; Calabrò, A. The salient role of institutions in Women's entrepreneurship: A critical review and agenda for future research. Int. Entrep. Manag. J. 2018, 14, 857-882. [CrossRef]

16. Henry, C.; Foss, L.; Ahl, H. Gender and entrepreneurship research: A review of methodological approaches. Int. Small Bus. J. 2016, 34, 217-241. [CrossRef]

17. Stead, V. Belonging and women entrepreneurs: Women's navigation of gendered assumptions in entrepreneurial practice. Int. Small Bus. J. 2017, 35, 61-77. [CrossRef]

18. Martin, R.L.; Osberg, S. Social Entrepreneurship: The Case for Definition; Stanford Social Innovation Review: Stanford, CA, USA, 2007; Volume 5, pp. 28-39.

19. Gaddefors, J.; Anderson, A.R. Entrepreneursheep and context: When entrepreneurship is greater than entrepreneurs. Int. J. Entrep. Behav. Res. 2017, 23, 267-278. [CrossRef]

20. Baumol, W.J. Entrepreneurship: Productive, unproductive, and destructive. J. Bus. Ventur. 1996, 11, 3-22. [CrossRef]

21. Anderson, A.; Ronteau, S. Towards an entrepreneurial theory of practice; emerging ideas for emerging economies. J. Entrep. Emerg. Econ. 2017, 9, 110-120. [CrossRef]

22. Alvord, S.H.; Brown, L.D.; Letts, C.W. Social entrepreneurship and societal transformation: An exploratory study. J. Appl. Behav. Sci. 2004, 40, 260-282. [CrossRef]

23. Boettke, P.J.; Coyne, C.J. Context matters: Institutions and entrepreneurship. Found. Trends Entrep. 2009, 5, 135-209. [CrossRef]

24. Welter, F.; Smallbone, D. Institutional perspectives on entrepreneurial behavior in challenging environments. J. Small Bus. Manag. 2011, 49, 107-125. [CrossRef] 
25. North, D.C. Institutions, Institutional Change and Economic Performance; Cambridge University Press: Cambridge, UK, 1990.

26. Jennings, J.E.; Brush, C.G. Research on women entrepreneurs: Challenges to (and from) the broader entrepreneurship literature? Acad. Manag. Ann. 2013, 7, 663-715. [CrossRef]

27. Bruton, G.D.; Ahlstrom, D.; Li, H.L. Institutional theory and entrepreneurship: Where are we now and where do we need to move in the future? Entrep. Theory Pract. 2010, 34, 421-440. [CrossRef]

28. Muhammad, N.; Warren, L.; Binte-Saleem, S. Anything Can Happen, Anytime: The Impact of Conflict on Women'S Entrepreneurship in Pakistan. J. Dev. Entrep. 2017, 22, 1750025. [CrossRef]

29. Knight, M. Race-ing, Classing and Gendering Racialized Women's Participation in Entrepreneurship. Gend. Work Organ. 2016, 23, 310-327. [CrossRef]

30. Scott, W.R. Approaching adulthood: The maturing of institutional theory. Theory Soc. 2008, 37, 427. [CrossRef]

31. Hanson, S. Geography and feminism: Worlds in collision? Ann. Assoc. Am. Geogr. 1992, 82, 569-586. [CrossRef]

32. Marlow, S.; Swail, J. Gender, risk and finance: Why can't a woman be more like a man? Entrep. Reg. Dev. 2014, 26, 80-96. [CrossRef]

33. Eddleston, K.A.; Powell, G.N. Nurturing entrepreneurs' work-family balance: A gendered perspective. Entrep. Theory Pract. 2012, 36, 513-541. [CrossRef]

34. Afshar Jahanshahi, A.; Brem, A.; Shahabinezhad, M. Does Thinking Style Make a Difference in Environmental Perception and Orientation? Evidence from Entrepreneurs in Post-Sanction Iran. Sustainability 2018, 10, 1546. [CrossRef]

35. Anderson, A.R.; Warren, L.; Bensemann, J. Identity, Enactment, and Entrepreneurship Engagement in a Declining Place. J. Small Bus. Manag. 2018. [CrossRef]

36. Welter, F.; Smallbone, D. Women's entrepreneurship from an institutional perspective: The case of Uzbekistan. Int. Entrep. Manag. J. 2008, 4, 505-520. [CrossRef]

37. McKeever, E.; Anderson, A.; Jack, S. Social embeddedness in entrepreneurship research: The importance of context and community. In Handbook of Research on Small Business and Entrepreneurship; Chell, E., Kasatas-Ozkan, M., Eds.; Edward Elgar: Cheltenham, UK, 2014; p. 222.

38. Amable, B. The Diversity of Modern Capitalism; Oxford University Press on Demand: New York, NY, USA, 2003.

39. Pakeeza, S. Domestic Violence Laws and Practices in Pakistan. VFAST Trans. Educ. Soc. Sci. 2015, 6. [CrossRef]

40. Qaisrani, A.; Liaquat, S.; Khokhar, E.N. Socio-economic and Cultural Factors of Violence against Women in Pakistan. Available online: http:/ / hdl.2016 (accessed on 5 May 2018).

41. Zaman, R.M.; Zaman, T.R.; Stewart, S.M. Pakistan: Culture, community, and filial obligations in a Muslim society. In Families across Cultures: A 30 Nation Psychological Study; James, G., Berry, J.W., Van de Vijver, F.J.R., Kagitçibasi, Ç., Poortinga, Y.H., Eds.; Cambridge University Press: Cambridge, UK, 2006; p. 427.

42. Mahmood, B.; Sohail, M.M.; Khalid, S.; Babak, I. Gender Specific Barriers to Women Entrepreneurs in Pakistan: A Study in Urban Areas of Pakistan. Br. J. Educ. Soc. Behav. Sci. 2012, 2, 339-352. [CrossRef] [PubMed]

43. Ali, P.A.; Gavino, M.I. Violence against Women in Pakistan: A Framework for Analysis. J. Pak. Med. Assoc. 2008, 58, 198-203.

44. Women in Pakistan (Asian Development Bank). Available online: https://www.adb.org/sites/default/ files/institutional-document/.../women-pakistan.pdf (accessed on 3 May 2018).

45. Kamal, A.; Woodbury, L. Emerging Opportunities for Women in Khyber Pakhtunkhwa. 2016. Available online: https:/ / www.theigc.org/wp-content/uploads/2016/04/Kamal-Woodbury-2016-Working-paper. pdf (accessed on 3 May 2018).

46. Haq, I. Gender Disparity in Khyber Pakhtunkhwa (Rural) with Respect to Education. 2016. Available online: http:/ / aserpakistan.org/document/aser_policy_briefs/2016/Gender-Disparity-in-KhyberPakhtunkhwa-Rural-with-respect-to-education.pdf (accessed on 5 May 2018).

47. Government of Pakistan Bureau of Statistics. Pakistan Social Living Standards Measurement Survey. 2015. Available online: http:/ / www.pbs.gov.pk/sites/default/files//pslm/publications/pslm2013_14/ A\%20report\%2013-14\%28\%2012-05-15\%29_FInal_1.pdf (accessed on 8 July 2018).

48. Rabbani, F.; Qureshi, F.; Rizvi, N. Perspectives on Domestic Violence: Case Study from Karachi, Pakistan. 2008. Available online: http:/ / www.who.int/iris/handle/10665/117454 (accessed on 4 May 2018). 
49. USAID. Gender Equality and Women Empowerment Policy. March 2012. Available online: https: / / www. usaid.gov/sites/default/files/documents/1865/GenderEqualityPolicy_0.pdf (accessed on 8 July 2018).

50. Karatas-Ozkan, M.; Anderson, A.R.; Fayolle, A.; Howells, J.; Condor, R. Understanding entrepreneurship: Challenging dominant perspectives and theorizing entrepreneurship through new postpositivist epistemologies. J. Small Bus. Manag. 2014, 52, 589-593. [CrossRef]

51. Silverman, D.; Marvasti, A. Doing Qualitative Research: A Comprehensive Guide; Sage: Thousand Oaks, CA, USA, 2008.

52. Denzin, N.K.; Lincoln, Y. Qualitative Research; Thousand Oaks UA: Thousand Oaks, CA, USA, 2000; pp. $413-427$.

53. Ukanwa, I.; Xiong, L.; Anderson, A. Experiencing microfinance: Effects on poor women entrepreneurs' livelihood strategies. J. Small Bus. Enterp. Dev. 2018, 25, 428-446. [CrossRef]

54. McElwee, G.; Al-Riyami, R. Women entrepreneurs in Oman: Some barriers to success. Career Dev. Int. 2003, 8, 339-346. [CrossRef]

55. Attride-Stirling, J. Thematic networks: An analytic tool for qualitative research. Qual. Res. 2001, 1, $385-405$. [CrossRef]

56. Moult, S.; Anderson, A.R. Enterprising women: Gender and maturity in new venture creation and development. J. Enterprising Cult. 2005, 13, 255-271. [CrossRef]

57. Hatch, J.A. Doing Qualitative Research in Education Settings; Suny Press: Albany, NY, USA, 2002.

58. Creswell, J.W.; Plano Clark, V.L.; Gutmann, M.L.; Hanson, W.E. Advanced mixed methods research designs. Handb. Mix. Methods Soc. Behav. Res. 2003, 209, 240.

59. Baughn, C.C.; Chua, B.L.; Neupert, K.E. The normative context for women's participation in entrepreneurship: A multicountry study. Entrep. Theory Pract. 2006, 30, 687-708. [CrossRef]

60. Roomi, M.A.; Parrott, G. Barriers to development and progression of women entrepreneurs in Pakistan. J. Entrep. 2008, 17, 59-72. [CrossRef]

61. Ahmed, L. Women and Gender in Islam; Yale University Press: New Haven, CT, USA, 1992.

62. Pratt, D. Religion and terrorism: Christian fundamentalism and extremism. Terror. Political Violence 2010, 22, 438-456. [CrossRef]

63. Blažková, O.D.I. Entrepreneurship and corruption: Do corruption perceptions influence regional entrepreneurial activity? Presented at the 12th International Days of Statistics and Economics, Prague, Czech Republic, 6-8 September 2018.

64. Williams, C.C.; Shahid, M.S. Informal entrepreneurship and institutional theory: Explaining the varying degrees of (in) formalization of entrepreneurs in Pakistan. Entrep. Reg. Dev. 2016, 28, 1-25. [CrossRef]

65. Kabeer, N. The Conditions and Consequences of Choice: Reflections on the Measurement of Women's Empowerment; UNRISD: Geneva, Switzerland, 1999; Volume 108, pp. 1-58.

66. Ahl, H. Why research on women entrepreneurs needs new directions. Entrep. Theory Pract. 2006, 30, $595-621$. [CrossRef]

(C) 2018 by the authors. Licensee MDPI, Basel, Switzerland. This article is an open access article distributed under the terms and conditions of the Creative Commons Attribution (CC BY) license (http:/ / creativecommons.org/licenses/by/4.0/). 